\title{
Protease Production from Immobilized Bacillus Subtilis and Its Application
}

\author{
Dr.K. Jagathy* \\ "Head \& Asst Prof. PG \& Reaserch Department of Microbiology, Sri Akilandeswari Women's College, \\ Vandavasi, T.V.Malai, Tamil Nadu, India.
}

\begin{abstract}
Biofilm is a complex aggregation of microorganisms growing on a solid substrate. Biofilms are characterized by structural heterogeneity, genetic diversity, complex community interactions, and an extracellular matrix of polymeric substances. Hence adherent cells are frequently embedded within a selfproduced matrix of extracellular polymeric substance (EPS). Biofilms have been found to be involved in a wide variety of microbial infections in the body, by one estimate $80 \%$ of all infections. Biofilms have been implicated in urinary tract infections, catheter infections, middle-ear infections, formation of dental plaque, gingivitis, coating contact lenses etc. The attachment cell and free cells from B. subtilis are used for the protease production. The presence of protease was confirmed by protease plate assay in both processes and the enzyme was estimation by biuret method. From the above analysis it is clear that applying this production process through this surface immobilization may suit well in fermentation industry in large scale fluidized bed reactor.
\end{abstract}

Keywords: Bacillus subtilis, Biofilm, Biuret method, Protease.

\section{Introduction}

Biofilms are grown in living and non-living surface. The microbial cells growing in a biofilm are physiologically distinct from planktonic cells of the same organism, which, by contrast, are single-cells that may float or swim in a liquid medium. In standing liquid medium, cells of $B$. subtilis switch from a submerged, highly motile planktonic state in which the bacteria swim as single cells, to a non-motile state in which the cells grow as bundled chains that rise to the surface and form a robust pellicle.

Biofilms can be defined as communities of microorganisms attached to a surface. It is clear that microorganisms undergo profound changes during their transition from planktonic (free-swimming) organisms to cells that are part of a complex, surface-attached community. These changes are reflected in the new phenotypic characteristics developed by biofilm bacteria and occur in response to a variety of environmental signals. Recent genetic and molecular approaches used to study bacterial and fungal biofilms have identified genes and regulatory circuits important for initial cell-surface interactions, biofilm maturation, and the return of biofilm microorganisms to a planktonic mode of growth. Studies to date suggest that the planktonic-biofilm transition is a complex and highly regulated process. The results reviewed in this article indicate that the formation of biofilms serves as a new model system for the study of microbial development.

Biofilms have been found to be involved in a wide variety of microbial infections in the body, by one estimate $80 \%$ of all infections. Infectious processes in which biofilms have been implicated include common problems such as urinary tract infections, catheter infections, middle-ear infections, formation of dental plaque, gingivitis, coating contact lenses, and less common but more lethal processes such as endocardiac, infections in cystic fibrosis, and infections of permanent indwelling devices such as joint prostheses and heart valves. More recently it has been noted that bacterial biofilms may impair cutaneous wound healing and reduce topical antibacterial efficiency in healing or treating infected skin wounds.

Protease is any enzyme that conducts proteolysis, that is, begins protein catabolism by hydrolysis of the peptide bonds that link amino acids together in the polypeptide chain. Proteases occur naturally in all organisms and constitute $1-5 \%$ of the gene content. These enzymes are involved in a multitude of physiological reactions from simple digestion of food proteins to highly regulated cascades.

Bacillus subtilis is also known as Hay bacillus or Grass bacillus. Bacillus subtilis is gram positive, rod shape, motile, spore forming bacteria. Bacillus subtilis commonly present in soil which is human pathogens.

The work describes the production of alkaline protease in a lab scale fermentor from Bacillus subtilis IH-72. The production of alkaline protease was enhanced by optimization of cultural conditions in a stirred fermentor. The alkaline protease so produced was applied to the goat skin for the removal of hair. The skin pieces were treated in three different ways; singly with the enzyme, in combination with the lime sulphide and singly with lime sulphide. The best results with the skin processing were obtained, when skin was treated with crude enzyme in combination with $7 \%$ lime sulphide. The quality of pelt (color, grain, stretch, scud etc) and physical properties of the finally prepared leather (tensile strength, tear strength, bursting strength etc) were also improved with the use of proteolytic enzymes produced by Bacillus subtilis. 


\section{Materials And Methods \\ CULTURING OF BACILLUS SUBTILIS ON LB AGAR \\ Culture: Bacillus subtilis \\ Procedure}

Prepared LB agar medium in sterile condition. The loop full of (Bacillus subtilis) culture is taking and streaked into LB agar medium. Then the flask was incubated at 24 hours at $37^{\circ} \mathrm{C}$.

\section{IDENTIFICATION TEST \\ Gram's staining}

A drop of test (Bacillus subtilis) MTCC culture was placed onto the clean grease free slide and this smear was made and air dried. The smear was then fixed gently and two drop of crystal violet for 2 minutes. The slide was washed gently with distilled water, and the slide was air dried. Then the smear was flooded with Gram's iodine and allowed to stand for 1 minute. The slide was again washed the procedure as mentioned above and the test smear was immersed in $95 \%$ ethyl alcohol and washed immediately and air dried. Few drops of counter strain ( $0.5 \%$ of safranin) was flooded onto the smear and kept for 1 minute. The slide was then washed, dried and observed under oil immersion using phase contrast microscope.

\section{Motility test (Hanging drop method)}

A tiny drop of fresh bacterial test culture was placed onto the coverslip. The coverslip were fixed in an inverted position in a clean cavity slide with the help of high vacuum grease and the edge of the drop was observed for the motility under the $10 \mathrm{X}$ power, then the slide was focused under $45 \mathrm{X}$ or oil immersion using contrast microscope.

\section{BIOCHEMICAL TEST}

Catalase test

A loop full of bacterial test culture was placed over the clean glass slide. A drop of $10 \%$ Hydrogen peroxide $\left(\mathrm{H}_{2} \mathrm{O}_{2}\right)$ was added to the drop of bacterial culture and the results were observed and recorded.

\section{Oxidase test}

$50 \mu \mathrm{l}$ of fresh bacterial test culture was placed onto the disc containing $\mathrm{N}, \mathrm{N}$-dimethyl paraphenylene diamine oxalate and alpha napthal to examine the indophenols blue the formation. The enzyme cytochrome oxidase present in same microorganisms, which oxidize the compound present in the disc and form an indophenols blue dye. The results observed within 20 seconds and recorded.

Urease test

Urease is a diamade of carbonic acid. Urease, the enzyme possessed by the bacterium hydrolyses urea and release ammonia and carbon-di-oxide. Ammonia results in solution to from ammonium carbonate, which is alkaline leading to increase in the $\mathrm{P}^{\mathrm{H}}$. Phenol red which is incorporated in the medium changes its color form yellow to red in alkaline $\mathrm{P}^{\mathrm{H}}$, thus indicating the presence of urease activity. The base was prepared and autoclaved at $121^{\circ} \mathrm{C}$ for 15 minutes. Cooled to $50^{\circ} \mathrm{C}$ in water bath and $5 \mathrm{ml}$ of filter sterilized $40 \%$ urea solution was added. A loop full of 24 hours culture from the Macconkey's agar was taken and inoculated in urea agar slant, incubated for 24 hours $37^{\circ} \mathrm{C}$ and the result were observed.

\section{SCREENING OF BACILLUS SUBTILIS FOR PROTEASE PRODUCTION}

These ingredients were dissolved in $100 \mathrm{ml}$ distilled water and adjusted to $\mathrm{P}^{\mathrm{H}} 7$ and sterilized at $121^{\circ} \mathrm{C}$ for 20 minutes at $15 \mathrm{Lbs}$. The Skim milk powders sterilized separately and were cooled to $45^{\circ} \mathrm{C}$ and to this add sterilized basal medium and poured into the plates.

\section{Procedure}

The isolated pure strains were screened for the production of extracellular alkaline protease production using screening medium such as Skim milk agar. The pure culture was streaked over the sterile milk agar plates and the plates were incubated at $37^{\circ} \mathrm{C}$ for 24 hours. The observation was made to see the substrate utilized zone around the colony.

\section{BIOFILM FORMATION OF BACILLUS SUBTILIS ON GLASS MATRIX Procedure}

First prepare biofilm induction media then added sterile glass matrix (glass slide). Then Bacillus subtilis culture are inoculated into induction media. The media are incubated for $24-48$ hours at $37^{0} \mathrm{C}$. After incubation the slide is carefully taken and washed with sterile water for two to three times. Then screening of Bacillus subtilis attachment over the glass slide by using staining. 
Confirmation of Bacillus subtilis attachment over the glass slide by Gram's staining technique

The slide was taken from the biofilm induction media and washed with sterile water in 3 times. Then the slide was fixed gently and two drop of crystal violet for 2 minutes. The slide was washed gently with distilled water, and the slide was air dried. Then the smear was flooded with Gram's iodine and allowed to stand for 1 minute. The slide was again washed the procedure as mentioned above and the test smear was immersed in $95 \%$ ethyl alcohol and washed immediately and air dried. Few drops of counter strain $(0.5 \%$ of safranin) was flooded onto the smear and kept for 1 minute. The slide was then washed, dried and observed under oil immersion using phase contrast microscope.

\section{BIOFILM FORMATION OF BACILLUS SUBTILIS ON NYLON BEADS Procedure}

First prepare biofilm induction media and added nylon beads. Then Bacillus subtilis culture was inoculated into induction media. The media are incubated in $24-48$ hours at $37^{\circ} \mathrm{C}$ in shaker condition.

\section{COMPARATIVE STUDY OF PROTEASE PRODUCTION PROCESS (FREE CELL AND ATTACHMENT CELL) \\ Procedure}

Surface immobilization (attached cell) of Bacillus subtilis for protease production

First prepared the protease production media. The attachment cell culture (nylon beads) is taken from the nutrient deficient media. The nylon beads washed with sterile water for two to three times. After washing the nylon beads are transfer into protease production media, and the media were transfer into sterile column. The column is stored in room temperature for 2-3 days.

Protease production by Bacillus subtilis (free cell)

Protease production media was taken in sterile conical flask. The Bacillus subtilis culture are inoculated into protease production media and incubate for 24 hours at $37^{\circ} \mathrm{C}$ and one day incubate for shaking condition.

\section{PROTEASE PLATE ASSAY}

Plate assay procedure

The $5 \mathrm{ml}$ of test culture are taken in centrifuge tube. The culture was centrifuged at $6000 \mathrm{rpm}$ for 15 minutes. The plate assay was performed using skim milk agar plates with $1.5 \%$ of agar. After solidification of the agar, around $10 \mathrm{~mm}$ diameter of well was cut out aseptically with the help of cork borer. The wells were filled with the centrifuged supernatant culture and incubated at $37^{\circ} \mathrm{C}$ over night. The observation was made to see the hydrolytic zone around the well. The negative control was maintained by adding the sterile water in the separate well.

\section{PROTEIN ESTIMATION BY BIURET METHOD Biuret Method}

The blank is prepared by adding $1 \mathrm{ml}$ of distilled water with $2 \mathrm{ml}$ of biuret reagent. $1 \mathrm{mg} / \mathrm{ml}$ concentration of Bovine serum standard solution can be prepared. The stock concentrations such as $0.1,0.2,0.3$, $0.4,0.5 \mathrm{ml}$ taken in each of the test tube and distilled water of $0.9,0.8,0.7,0.6,0.5 \mathrm{ml}$ added to each of the test tube containing the stocks respectively. To all the test tubes $2 \mathrm{ml}$ of biuret reagent is added. The test samples of $1: 10,1: 15,1: 20$ about $1 \mathrm{ml}$ is taken and diluted to 10 fold, taken in separate test tubes along with the $2 \mathrm{ml}$ of biuret reagent. All the test tubes were left undisturbed for 45 minutes. The tubes were read at $550 \mathrm{~nm}$.

\section{Results}

\section{SCREENING OF BACILLUS SUBTILIS FOR PROTEASE PRODUCTION}

The isolated pure strains were screened for the production of extracellular alkaline protease production using screening medium such as Skim milk agar. After incubate the well surround by zone. This indicates protease produced by Bacillus subtilis.

\section{PROTEASE PRODUCTION}

The enzyme was collected from the column after 2-3 days of incubation. The nylon beads filled with protease production media.

\section{COMPARATIVE STUDY OF PROTEIN ESTIMATION (FREE CELL AND ATTACHMENT) BY BIURET METHOD}

The optical density was measured at $550 \mathrm{~nm}$ for free cell and attachment cell. 


\begin{tabular}{|c|c|c|c|}
\hline \multicolumn{1}{|c|}{ OD value for Biuret test } \\
S. No & Sample & $\begin{array}{c}\text { OD value of attachment cell } \\
(620 ~ \mathbf{~ m})\end{array}$ & OD value of free cell(620 nm) \\
\hline 1. & $0.1 \mathrm{ml}$ & 0.16 & 0.11 \\
\hline 2. & $0.2 \mathrm{ml}$ & 0.29 & 0.18 \\
\hline 3. & $0.3 \mathrm{ml}$ & 0.37 & 0.31 \\
\hline 4. & $0.4 \mathrm{ml}$ & 0.45 & 0.40 \\
\hline 5. & $0.5 \mathrm{ml}$ & 0.53 & 0.48 \\
\hline
\end{tabular}

\section{Discussion}

In this work describe the surface immobilization organism produced protease enzyme production. In the microbial world, existence within surface-associated structured multi-cellular communities may be the rule, rather than the exception. The organizing principle afforded by surfaces appears to have been universally exploited by microbes during the course of evolution; most microorganisms appear to be capable of forming biofilms of some sort or another. Molecular genetics approaches have begun to elucidate the mechanisms by which microbes build such communities. Comparison of biofilm formation by many different organisms has led to the appreciation that the extracellular matrix is absolutely essential for biofilm structure (Steave Branda et al., 2006). Different matrices like agar, gelatin, sodium alginate and polyacrylamide were used for immobilization of a definite amount of logarithm phase, B. subtilis cells. A free cell system containing the equivalent cell weight was also run, similarly. Represent the comparative protease production by different matrices over a time period of $48 \mathrm{~h}$ of incubation and cell leakage, respectively Immobilization of protease producing cells has practiced by many authors (Anwar et al., 2009)

Among the immobilization methods for biofilm cells, entrapment is the most suitable and common method of practice. Immobilization by entrapment is known to be a simple and gentle procedure and keeps the cells from unfavorable conditions $(\mathrm{pH}$, temperature, etc) found in the surrounding media (Fukui and Tanaka, 1982; Kierstan and Ducke 1977). Whole cell immobilization technique is generally being used for higher productivity by protecting the cells from shear forces, in addition to this the product and cell separation is easy so that the cells can be reused several times (Adinarayana et al., 2005).

The attachment cell and free cell are using the protease production. The protease production media are used in protease production. The presence of protease was confirmed by protease plate assay in both processes and the enzyme was estimation by biuret method. From the above analysis it is clear that applying this production process through this surface immobilization may suit well in fermentation industry in large scale fluidized bed reactor.

\section{Reference}

[1] Adinarayana, K. Jyothi, B and Ellaiah, P. 2005. Production of Alkaline Protease with Immobilized Cells of Bacillus subtilis. AAPS PharmSciTech; 6: (3) 48-52.

[2] Champion Lee I-Ming Chu and Tsu-Shun Li. 2002. The protease enzyme production and immobilization. Enzyme and Microbial Technology 14: 9, 755-76.

[3] Chapman, J. W and Piggot, P. J. 1987. Analysis of the inhibition of sporulation of Bacillus subtilis caused by increasingthe number of copies of the spoOF gene. J. Gen. Microbiol. 133:2079-2088.

[4] Eric, D. van Hullebusch,. Marcel, H. Zandvoort and Piet, N.L. 2003. Lens Metal immobilisation by biofilms: Reviews in Environmental Science and Biotechnology. 2: 9-33.

[5] Fukui, S and Tanaka, A. 1982. Immobilized microbial cells. Ann. Rev. Microbiol., , 36: 145-172.

[6] Kearns, D.B., Losick, and Swarming,.R. 1991. Motility in undomesticated Bacillus subtilis. Mol Microbiology 49: 581-590.

[7] Kierstan, M., and Ducke. 1977, Immobilization of microbial cells sub-cellular organelles and enzymes in calcium alginate gels. Biotechnol. Bioeng., 19: 337-397.

[8] Makoto Ashiuchi, Tohru Kamei and Haruo Misono 2003. Poly- $\gamma$-glutamate synthetase of Bacillus subtilis. Journal of Molecular Catalysis B: Enzymatic. 23: 2-6, 783-8502.

[9] Noguera, D.R., Pizarro, G., Stahl, D.A. and Rittmann, B.E. 1999. Simulation of multispecies biofilm development in three dimensions. Wat. Sci. Tech., 39(7), 123-130.

[10] Picioreanu, C., van Loosdrecht, M.C.M. and Heijnen,J.J. 1999. Mathematical modeling of biofilm structure with a hybrid differential discrete cellular automaton approach. Bitechnology Bioengineering. 58: 101-116.

[11] Rakesh Kumar and Ritika Vats. 1998. Protease Production by Bacillus subtilis. Immobilized on Different Matrices Biotechnology. 2: 3, 222-234.

[12] Shafikhani, S.H., Mandic-Mulec, I., Strauch, M.A., Smith, I. and Leighton, T. 2002 Postexponential regulation of sin operon expression in Bacillus subtilis. J Bacteriology. 184: 564-571.

[13] Van Tilbeurgh, H., Manival, X., Aymerich, S., Lhoste, J. M. Dumas, C. and Kochoyan, M. 1997. Crystal structure of a new RNAbinding domain from theantiterminator protein SacY of Bacillus subtilis. EMBO J. 16: 5030-5036.

IOSR Journal of Pharmacy and Biological Sciences (IOSR-JPBS) is UGC approved Journal with Sl. No. 5012, Journal no. 49063.

Dr.K. Jagathy. "Protease Production from Immobilized Bacillus Subtilis and Its Application." IOSR Journal of Pharmacy and Biological Sciences (IOSR-JPBS) 12.4 (2017): 34-37. 